\title{
8
}

\section{Keeping fiscal policy sustainable in China: challenges and solutions}

\author{
Jinzhi Tong and Wing Thye Woo
}

Among doomsayers of all stripes, a favourite mechanism for the forthcoming collapse of the economy is the inevitable fiscal crisis of the State. The Marxist economist James O'Connor (1973) predicted that the dynamics of capitalist America would precipitate a fiscal crisis that would completely destabilise the economy. In turn, the capitalist lawyer Gordon Chang (2001) predicted that a fiscal crisis could be the triggering event for the unavoidable disintegration of socialist China.

This fixation by the doomsayers on a large negative fiscal shock as a destructive systemic shock is understandable because fiscal imbalance is the proximate cause in most crises. The reason is that the state budget is often faced with the task of defusing the cumulative tensions unleashed by deeper, more fundamental social processes. To a first approximation, fiscal capacity is a fundamental determinant of system stability because economic sustainability depends on the ability to cover production costs, and political viability depends on the ability to reward one's supporters and to pay off one's enemies.

The reality in many cases is that fiscal sustainability is the prerequisite for economic sustainability and political viability, which are intricately linked and mutually reinforcing. To see the mutual interdependence of the two, one has only to recall the many times that near-bankrupt governments have been driven out of power after raising the prices of a subsidised item such as food, petrol or foreign exchange. ${ }^{1}$ One could go so far as to say that the degree of economic and political resilience of a state can be measured by the State's ability to cover an unexpected, 
prolonged increase in expenditure or an unanticipated, protracted shortfall in revenue. $^{2}$

A recent $O E C D$ report raised grave concerns about China's fiscal management. Specifically,

China's officially reported spending figures reflect only about three-quarters of total government spending. Extra-budgetary spending, social security outlays and central government bond financing of local projects are not part of the official budget. Notwithstanding recent reforms, the government remains overly exposed to extra-budget and off-budget activities, which make public expenditures difficult to plan and control and which impair their accountability and transparency. Contingent liabilities have been a major source of unplanned spending and pose perhaps the greatest risk to the controllability of future expenditure (OECD 2006:10).

We share the concerns expressed in this report. We want to add that there are other equally important concerns about China's fiscal situation (for example, there are fundamental improvements that should be made to the public revenue side), and there is the even more important issue of fiscal sustainability. In our opinion, fiscal sustainability is more important than fiscal efficiency because the former determines the survival of the system, while the latter influences only the output growth rate.

In this chapter, we report the results from two different approaches to analyse the issue of fiscal sustainability

- the standard stock-flow analysis that focuses on the amount of public debt outstanding and the path of annual budget deficits

- the newer generational accounts approach that focuses on the difference between the tax burdens of the current generation and future generations of taxpayers.

We use both approaches because, as will become clear, they emphasise different aspects of the sustainability issue in fiscal management. ${ }^{3}$ In the stock-flow approach, the level of fiscal sustainability is indicated by the level of the steadystate debt-GDP ratio. In the extreme case of an explosive path for the debt-GDP ratio, the fiscal regime is definitely unsustainable. In the case of a very high steady-state debt-GDP ratio, especially when the value is beyond the international experience, this fiscal regime is deemed vulnerable to fiscal crises, for example, the cause could be an unexpected jump in emergency expenditure.

In this chapter, we give to the generational accounting approach an interpretation of sustainability that we have not seen discussed in the literature. ${ }^{4}$ Our interpretation is that the degree of intergenerational inequity is a measure of fiscal sustainability. If the tax burden of future generations is found to be much larger than the tax burden of the generation born today, present interest rates will be 
higher if financial markets perceive the possibility of high future taxes leading to a future tax revolt and/or future debt repudiation through inflation. In the extreme case, where debt repudiation is seen as certain, markets would refuse to finance the deficit, making the fiscal regime immediately unsustainable.

To get ahead of the analysis, our conclusions are that

- the present fiscal regime is sustainable, but China's low revenue-GDP ratio and its repeated recapitalisation of the state banks have made China vulnerable to a fiscal crisis

- the vulnerability to a fiscal crisis could be reduced easily with some straightforward reforms in the management of state assets, and in the regulatory regime of the financial sector

- the existing fiscal regime is highly inequitable towards future generations

- the intergenerational inequity could be reduced easily by reasonable reform of the pension system.

\section{The stock-flow approach to fiscal sustainability}

The fact that fiscal sustainability is central to economic management can be seen in the two fiscal targets that the original Growth and Stability Pact of the countries in the Euro-Zone specified for its members to meet

- the consolidated government budget deficit should not exceed 3 per cent of GDP except in the case of an unusually severe downturn

- the debt-GDP ratio should be brought down to 60 per cent or lower.

Table 8.1 gives an international perspective on the fiscal situation in China by comparing it with those of the OECD countries. We chose the year 2001 for China because we wanted to postpone until later discussion the fiscal consequences of the continuing recapitalisation of the state-owned banks. We use the year 2003 for OECD countries because the cross-country data for that year were conveniently available. ${ }^{5}$ Table 8.1 reports that China's official debt-GDP ratio was 16.4 per cent, and compared favourably with the OECD average of 75.3 per cent. If we treat the tiny state of Luxembourg as an exception and exclude it from the comparison, the lower half of the OECD distribution of debt-GDP ratios ranges from 18.6 per cent (South Korea) to 55.5 per cent (Denmark); and the upper half of the distribution ranges from 58.1 per cent (Hungary) to 154 per cent (Japan).

As China's debt-GDP ratio of 16.4 per cent is below the 18.6 per cent of South Korea, and as China's annual budget deficit has nearly always been below 3 per cent of GDP, it would seem that China has a sounder fiscal situation than all the OECD countries. ${ }^{6}$ Such an impression, however, needs to be qualified. Many 
Table 8.1 Comparative perspectives on the size of the national debt, 1995 and 2003 (as a per cent of GDP)

(I)OECD's fiscal situation

\begin{tabular}{|c|c|c|c|c|}
\hline & \multicolumn{2}{|c|}{$\begin{array}{l}\text { General government } \\
\text { gross financial liabilities }\end{array}$} & \multicolumn{2}{|c|}{ Total tax revenue } \\
\hline & 1995 & 2003 & 1995 & 2003 \\
\hline Luxembourg & 6.7 & 6.7 & 42.3 & 41.3 \\
\hline Korea & 5.5 & 18.6 & 19.4 & 25.3 \\
\hline Australia & 43.4 & 18.9 & 29.8 & 31.6 \\
\hline Ireland & 81.2 & 31.1 & 32.8 & 29.7 \\
\hline New Zealand & 51.7 & 32.0 & 36.9 & 34.9 \\
\hline Iceland & 59.4 & 41.4 & 32.1 & 39.8 \\
\hline United Kingdom & 52.7 & 41.9 & 35.1 & 35.6 \\
\hline Czech Republic & 19.3 & 46.8 & 37.5 & 37.7 \\
\hline Slovakia & n.a. & 49.7 & n.a. & 31.1 \\
\hline Norway & 40.5 & 50.4 & 41.1 & 43.4 \\
\hline Finland & 65.1 & 52.0 & 46.0 & 44.8 \\
\hline Poland & n.a. & 52.1 & 37.0 & 34.2 \\
\hline Spain & 68.8 & 54.8 & 31.8 & 34.9 \\
\hline Denmark & 77.6 & 55.5 & 49.5 & 48.3 \\
\hline Hungary & n.a. & 58.1 & 42.4 & 38.5 \\
\hline Sweden & 82.2 & 59.8 & 48.5 & 50.6 \\
\hline Netherlands & 87.0 & 61.9 & 41.9 & 38.8 \\
\hline United States & 74.2 & 63.4 & 27.9 & 25.6 \\
\hline Germany & 55.8 & 64.6 & 37.2 & 35.5 \\
\hline Portugal & 69.9 & 66.6 & 33.6 & 37.1 \\
\hline Austria & 69.6 & 69.4 & 41.1 & 43.1 \\
\hline France & 62.6 & 71.7 & 42.9 & 43.4 \\
\hline Canada & 100.8 & 75.7 & 35.6 & 33.8 \\
\hline Belgium & 135.2 & 103.2 & 44.8 & 45.4 \\
\hline Greece & 108.7 & 108.8 & 32.4 & 35.7 \\
\hline Italy & 125.5 & 121.4 & 41.2 & 43.1 \\
\hline Japan & 87.0 & 154.0 & 26.7 & 25.3 \\
\hline OECD total & 72.8 & 75.3 & 35.7 & 36.3 \\
\hline
\end{tabular}

(II)China's fiscal situation

Debt-GDP (per cent)

2001

Official data

16.4

\begin{tabular}{lcc}
\multicolumn{3}{c}{ Revenue-GDP (per cent) } \\
1995 & 2001 & 2007 estimate \\
10.7 & 16.8 & 21.6
\end{tabular}

Revised debt-GDP ratio in 2001 after taking into account

(a) 2nd recapitalisation costs

Citigroup (2002)

65.9

Fan (2003) (b) all contigent liabilities

114.9

74.7

Sources: OECD data available from http://stats.oecd.org/wbos/

viewhtml.aspx?QueryName=2\&QueryType=View\&Lang=en. China revenue data for 1995 and 2001 from National Bureau of Statistics of China, 2005a. China Statistical Yearbook 2005, China Statistics Press, Beijing. Revenue estimate for 2007 is from Deutsche Bank (2006). 
analysts have noted that China's official debt-GDP ratio understates the extent of the country's fiscal burden because it does not include the non-performing loans in the state-owned banks that the State would have to take over during recapitalisation, and it does not include many contingent liabilities (for example, pension schemes of state enterprises) that the State would have to assume responsibility for in order to preserve economic and social stability. Citigroup (2002), for example, estimated that the cost for state-owned bank recapitalisation was 46.9 per cent of GDP, social security obligations were 26.1 per cent and external debts were 15.6 per cent.

Part two of Table 8.1 uses estimates from Citigroup (2002) and Fan (2003) to revise China's official debt-GDP ratio. The outcomes are that China's debt-GDP ratio is 57.4 to 65.9 per cent when only state-owned bank recapitalisation is undertaken and 74.7 to 114.9 per cent when all contingent liabilities are recognised.

This change in China's debt-GDP ratio

- moves China from the bottom of the OECD distribution to the top half of the distribution

- in the worst-case scenario, puts China in the group of the five OECD countries with the highest ratios: 74.7-114.9 per cent for China versus 75.7 per cent for Canada, 103.2 per cent for Belgium, 108.8 per cent for Greece, 121.4 per cent for Italy and 154 per cent for Japan.

Should the much higher revised debt-GDP ratio raise concern about China's fiscal sustainability? Our cautious reading of the evidence is that a fiscal crisis in China is not imminent. China's ratio not only falls within the OECD experience, its worst-case ratio of 114.9 per cent is still lower than Italy, which has had a satisfactory overall economic performance. Most importantly, China's ratio is still substantially lower than the highest OECD ratio of 154 per cent (Japan).

While we believe that China's fiscal regime is sustainable, we do think that there are two fiscal features that have rendered the fiscal system vulnerable to a crisis. The first is that China has a lower capacity to service its public debt than all the OECD countries. While China's revenue-GDP ratio has been increasing rapidly, from 10.7 per cent in 1995 to 16.8 per cent in 2001, and to an expected 21.6 per cent in 2007, the 2007 level is still low by OECD standards.

The average revenue-GDP ratio in the OECD in 2003 was 36.3 per cent, with the three lowest ratios (25.3 per cent for Japan and South Korea, and 25.6 per cent for the United States) higher than China's. While China's best-case debtGDP ratio of 57.4-65.9 per cent puts it in the same group as Denmark (55.5 per cent), Hungary (58.1 per cent), Sweden (59.8 per cent) and the Netherlands (61.9 
per cent), China's revenue-GDP ratio is only 21.6 per cent compared with Denmark's 48.3 per cent, Hungary's 38.5 per cent, Sweden's 50.6 per cent and the Netherlands' 38.8 per cent. For the OECD countries with debt-GDP ratios similar to China's worst-case ratio of 74.7-114.9 per cent, all also have higher revenue-GDP ratios: 21.6 per cent for China versus 33.8 per cent for Canada, 45.4 per cent for Belgium, 35.7 per cent for Greece and 43.1 per cent for Italy.

The important point about this first fiscal feature is that as China's public debt rises from 16.4 per cent of GDP to 74.7 per cent with the incremental assumption of the contingent liabilities, the State will have to reduce expenditure steadily to accommodate the additional debt service unless there is an increase in state revenue.

The second feature that renders China vulnerable to a fiscal crisis is the constant need to recapitalise the state-owned banks. In 1998, state-owned banks were recapitalised to bring the average capital adequacy ratios (CAR) of the four biggest state-owned banks (the 'big four') to more than 8 per cent at the end of that year, but subsequent losses reduced the average CAR of the big four to 5 per cent at the beginning of 2002, making another recapitalisation necessary (see details in Tong and Woo 2006).

It needs to be emphasised that the incremental recapitalisation of state-owned banks that has been going on since 2003 is the second such recapitalisation. The serious implication is that if a third recapitalisation were to occur in the future, China's debt-GDP ratio would rise to the 154 per cent level of Japan, a country that suffered an economic stagnation that lasted more than 10 years.

The important point from this second fiscal feature is that the government cannot afford to continue recapitalising the state-owned banks; indeed, this is possibly the last time it can do so without upsetting confidence in the financial markets about the soundness of China's fiscal regime.

This point about the present recapitalisation being the last is confirmed by the dynamic analysis of the debt-GDP ratio in Tong and Woo (2006), who show that constant recapitalisation of the state-owned banks would make fiscal management very difficult. China can afford constant recapitalisation of the state-owned banks only if its long-term annual growth rate (say, for the next 80 years) is 9.5 per cent or higher. In the Tong and Woo (2006) analysis, the usual scenario of a long-term growth rate of 8 per cent would still produce a debt-GDP ratio that was too high.

How difficult is it to raise China's revenue-GDP ratio and to stop losses in the state-owned banks in order to ensure fiscal sustainability? With regard to raising state revenue, we make two interrelated observations. 
The first is that since the State has the right to raise taxes, it is a mystery that fiscal crises have happened so often and in many parts of the world. In theory, a government faced with a repayment of principal could impose a new tax on bondholders and then use this new revenue to redeem the bonds. In practice, however, such an act would be perceived correctly as a confiscation of wealth by a profligate (possibly also incompetent) government, and could lead to political unrest that toppled the government. In short, even though governments can introduce new taxes at any time, this is an option many are cautious about exercising for political reasons. The worry is that raising taxes might be interpreted by the populace in the same way that a currency devaluation is usually interpreted-as a failure of governance.

The second observation about tax-raising ability is that the G-7 countries with the highest revenue-GDP ratios are in western Europe: for example, France (43.4 per cent), Germany (35.5 per cent), Italy (43.1 per cent) and the United Kingdom (35.6 per cent), versus the United States (25.6 per cent) and Japan (25.3 per cent). In these western European countries, citizens voted in politicians who then raised taxes to finance social democratic programs (for example, subsidised universal health care, subsidised higher education and public pension schemes).

The reasons why the United States has low taxes and fewer social programs than western Europe are many and complex, but two are that the United States was founded on the basis of a tax revolt against England and it has a stronger cultural emphasis on individualism. In short, a government could raise taxes and survive politically only if the citizens liked these state-provided services and were willing to pay for them. This explains why the highest tax burdens are found in democracies and not in authoritarian societies: the taxes could be collected in the former only because the people had agreed to their imposition and to their intended use.

On the issue of how to raise China's revenue-GDP ratio to make the fiscal regime sustainable, our opinion is that the ratio is unlikely to continue growing at the speed of the 1995-2001 period because the value-added tax (VAT) and the company income tax are becoming the main sources of state revenue-and these are flat not progressive taxes. Therefore, China's revenue-GDP ratio is unlikely to increase much more unless new taxes or higher tax rates are introduced. Because we doubt that it would be popular for the Chinese government to raise taxes in the name of covering the losses of the banks and of taking over the pension schemes of state enterprises, we think that it might be more astute politically to generate the needed revenue by selling state assets.

The solution for stopping the losses in the state-owned bank sector (the second requirement for fiscal sustainability) lies in imposing a hard budgetary constraint 
on the banks. State-owned bank managers have to be convinced that the present recapitalisation will be the last free supper (which the 1998 recapitalisation was announced as), and that their compensation and promotion will depend solely on the profitability of their banks relative to private banks.

At the same time, the prudential supervision and monitoring of bank operations will have to be strengthened to prevent asset stripping and to discourage reckless investments fostered by the asymmetrical reward system under the soft budget constraint. ${ }^{7}$ The operations of state-owned banks could be improved further by bringing in foreign strategic investors who would be part of the management team, and by removing the influence of local governments on bank operations.

One additional way to harden the budgetary constraint faced by the state-owned banks is to privatise some of their branches and use the performance of the new private banks to gauge the performance of the remaining state-owned banks. The privatisation of some branches will also help convince the state-owned bank managers that the government is serious when it says the present recapitalisation will be the last free supper.

\section{The generational accounting approach to fiscal sustainability}

The generational accounting approach to evaluating fiscal policy pioneered by Auerbach et al. (1991) represents a clever reframing of the question about fiscal sustainability by operationalising the principle of 'there is no such thing as a free lunch'. The question of sustainability is not answered with 'yes', 'no', 'maybe' or 'it depends', it is answered by estimating the tax burden that future generations would have to bear in order for the present fiscal regime to be sustained. ${ }^{8}$ What permits the estimation of this future tax burden is the imposition of the inter-temporal budget constraint on government finances. Whatever budget deficits a government runs today and has incurred in the past will have to be repaid by future budget surpluses.

The government, in short, cannot keep rolling over its debt and borrowing additional amounts to make interest payments and cover new deficits. This restriction thus rules out the existence a non-zero steady-state debt-GDP ratio because it regards a 30 per cent ratio as being just as unsustainable as a 3,000 per cent ratio. This implication is obvious once we recognise that the non-technical translation of the term 'inter-temporal budget constraint' is that no one (including the government) can create a free lunch for itself by employing a Ponzi game. The proponents of generational accounting do not identify explicitly (at least in the readings we have undertaken so far) what mechanism exists to prevent such a Ponzi game. The answer presumably is that the financial markets would step in by refusing to fund the bonds, giving them a zero price. 
Generational accounting is based on the government's inter-temporal budget constraint, written as equation (1), which implies that the future net tax payments of current and future generations should be sufficient, in present value, to cover the present value of the government's future purchases plus its initial net debt. The term 'net payments' refers to the difference between government tax receipts of all types and government transfer payments of all types.

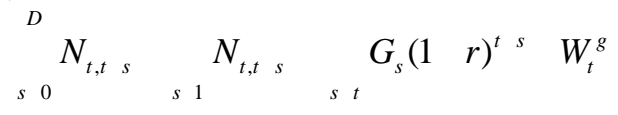

All terms in (1) are real values, that is, they are measured at constant prices. The first summation on the left-hand side of (1) adds together the generational accounts of existing generations. The term $N_{t, k}$ stands for the generational account of generation $k$ and it equals the present value of the average remaining lifetime net tax payment at time $t$ of the generation born in year $k$. The index $k$ in this summation runs from $t-D$ (where $D=$ the maximum length of life) to $t$ in order to sum up the sum of the existing generations.

The second summation on the left side of (1) adds together the present values of the generational accounts of future generations, with $k$ again representing the year of birth. The first term on the right-hand side of (1) expresses the present value of government purchases. The values of government purchases in year $s$, given by $G_{s}$, are also discounted to year $t$. The term $r$ is the government's real before-tax discount rate. The remaining term on the right-hand side denotes the government's net wealth-its financial assets minus the sum of its financial liabilities and the market value of its public enterprises.

Generational accounts are defined specifically as the present value of net taxes (taxes paid minus transfer payments received) that individuals of different age cohorts are expected, under current policy, to pay over their remaining lifetimes. The generational account $N_{t, k}$ is defined by

$$
N_{t, k} \quad \underset{s \max (t, k)}{K D} T_{s, k} P_{s, k}\left(\begin{array}{ll}
1 & r)^{t s}
\end{array}\right.
$$

In equation (2), $T_{s, k}$ stands for the projected average net tax payment to the government made in year $s$ by a member of the generation born in year $k$. The term $P_{s, k}$ stands for the number of surviving members of the cohort in year $s$ who 
were born in year $k$. In the case of generations who are born before year $t$, the summation begins in year $t$ and is discounted to year $t$. For generations born in year $k>t$, the summation begins in year $k$ and is discounted to year $t$.

Given the right-hand side of equation (1) and the first term on the left-hand side of equation (1), we determine, as a residual, the value of the second term on the left-hand side of equation (1): the collective payment required of future generations. Based on this amount, the average present-value lifetime net tax payment of each future generation can be determined under the assumption that these payments rise for members of each successive future cohort at the economy's rate of labour productivity growth, $g$-that is, the net tax amount will increase by 10 per cent when income increases by 10 per cent.

So the growth-adjusted net tax of future generations is directly comparable with the per capita net tax payment of current newborns, which is equal to $N_{t, t}$ divided by $P_{t, t}$, because the generational accounts of newborns and future generations take into account net tax payments over these generations' entire lifetimes. The use of growth-adjusted net tax for the future generations means that if it is higher (lower) than the net tax of the zero-age generation then the future generation is paying a higher (lower) tax rate than the zero-age generation.

If the net tax payments (after adjustment of income growth) of each member of the future generations equals $\frac{N_{t, t}}{P_{t, t}}$, then generational policy is balanced; and if it exceeds (is smaller than) $\frac{N_{t, t}}{P_{t, t}}$, then a member of the future generations faces a larger (smaller) growth-adjusted lifetime net tax burden than do current newborns.

It should be noted that the generational accounts reflect only taxes and social insurance contributions paid less transfers received (including education, health and social security expenditures). The generational accounts do not show the net benefit or net burden that any generation receives from all government policies; they can show the change in a generation's net benefit (or net burden) from a particular policy change only if the impact of this change falls exclusively on taxes and transfers. Thus, generational accounting can tell us only which generations will pay for government spending; it does not tell us which generations will benefit from that spending. Furthermore, generational accounting does not incorporate induced behavioural effects to policy changes.

\section{Applying the generational accounts approach to China}

A recent paper by Jiang et al. (2006), henceforth referred to as JRW, applied the generational accounts framework to study China's fiscal situation. ${ }^{9}$ The standard generational accounting approach separates the members of each generation into males and females. JRW has another fundamental dichotomy: urban residents 
versus rural residents, because most state institutions, including the tax social security systems, treat these two types of residents very differently.

Because China is a developing transitional economy that is changing very rapidly, the JRW analysis projected significant changes to the present patterns in population location, demographic distribution, output growth and institutional arrangements. For example, JRW built into the generational accounts the rural-to-urban migration process and the expansion of the social security system. Also because of the paucity of data that are required to draw reasonable assumptions on the incidence of taxes to members of each generation, JRW settled on the heuristic practice of producing two estimates (Net Payment 1 and Net Payment 2) for the distribution of the taxes and transfers.

JRW constructed Net Payment 1 in two steps

(a) distributed the aggregate amount in each category in the base year by age, sex and status based on relative age-sex-status tax profiles and age-sexstatus transfer profiles that were derived from cross-section micro data sets; and

(b) assumed that these two profiles in the future would be the same as in the base year, with an adjustment for growth.

JRW constructed Net Payment 2 by distributing all taxes by an age-sex-status consumption profile.

\section{The burden on future generations-the base case}

Table 8.2 reports the JRW estimates of per capita net tax payments for urban males and females and rural males and females under the base case for the two different assumptions on the incidence of taxes and transfers. It shows positive values for the accounts of young and middle-aged urban cohorts alive in 2002, indicating that each member of these generations will, on average, pay more in present value than they receive.

For the urban males aged 46 and older, the generational accounts are negativethat is, the present value of the transfers they will receive exceed the present value of the taxes they will pay. The generational accounts are negative for urban females aged 40 and older. The younger age at which this switch occurs for urban females is attributable to their lower labour force participation rates and earlier retirement age.

For rural cohorts, the generational accounts are positive throughout their life span. This reflects the small amount of transfers that aged rural residents receive from the State. 


\section{Table 8.2 Per capita net tax payments for different cohorts in JRW's base case simulation}

\begin{tabular}{|c|c|c|c|c|c|c|c|c|}
\hline \multirow[t]{2}{*}{ Age in 2002} & \multicolumn{2}{|c|}{ Urban male } & \multicolumn{2}{|c|}{ Urban female } & \multicolumn{2}{|c|}{ Rural male } & \multicolumn{2}{|c|}{ Rural female } \\
\hline & $\begin{array}{l}\text { Net Tax } \\
\text { (1) }\end{array}$ & $\begin{array}{l}\text { Net Tax } \\
\text { (2) }\end{array}$ & $\begin{array}{l}\text { Net Tax } \\
\text { (1) }\end{array}$ & $\begin{array}{c}\text { Net Tax } \\
\text { (2) }\end{array}$ & $\begin{array}{l}\text { Net Tax } \\
\text { (1) }\end{array}$ & $\begin{array}{l}\text { Net Tax } \\
\text { (2) }\end{array}$ & $\begin{array}{l}\text { Net Tax } \\
\text { (1) }\end{array}$ & $\begin{array}{c}\text { Net Tax } \\
\text { (2) }\end{array}$ \\
\hline 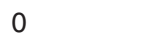 & 55,439 & 52,924 & 30,292 & 28,086 & 16,964 & 21,431 & 11,995 & 18,218 \\
\hline 10 & 71,749 & 66,499 & 40,198 & 34,606 & 24,395 & 27,131 & 16,839 & 22,040 \\
\hline 20 & 92,334 & 82,916 & 54,443 & 44,524 & 34,096 & 33,536 & 21,988 & 24,955 \\
\hline 30 & 82,597 & 75,044 & 42,728 & 35,973 & 32,328 & 33,424 & 19,725 & 24,423 \\
\hline 40 & 37,410 & 34,731 & $-5,027$ & $-6,1$ & 25,649 & 29,757 & 15,389 & 22,068 \\
\hline 50 & $-24,446$ & $-21,471$ & $-51,094$ & $-47,173$ & 16,472 & 23,980 & 9,809 & 18,207 \\
\hline 60 & $-43,350$ & $-40,287$ & $-49,744$ & $-45,440$ & 7,708 & 13,733 & 6,036 & 12,876 \\
\hline 70 & $-81,314$ & $-78,100$ & $-29,118$ & $-25,066$ & 3,836 & 8,108 & 3,587 & 8,634 \\
\hline 80 & $-64,941$ & $-63,262$ & $-17,081$ & $-14,801$ & 2,151 & 4,525 & 2,144 & 5,074 \\
\hline 90 & $-43,208$ & $-42,430$ & $-10,526$ & $-9,400$ & 1,269 & 2,589 & 1,199 & 2,748 \\
\hline Futur & 79,633 & 74,379 & 43,511 & 39,472 & 24,367 & 30,1 & 17,230 & 25,604 \\
\hline Ratio & 1.4364 & 1.4054 & 1.4364 & 1.4054 & 1.4364 & 1.4054 & 1.4364 & 1.4054 \\
\hline
\end{tabular}

Note: Net Payment 1 (Net Tax 1) assumes that the taxes are borne by those paying them; and Net Payment 2 (Net Tax 2) assumes that all taxes are distributed by age-sex-status consumption profiles.

Source: Reproduced from Jiang, Y., Ruoen, R. and Woo, W.T., 2006. A generational accounts analysis of China's fiscal fituation: que sera sera, the future's not ours to see?, manuscript, University of California.

The row in Table 8.2 labelled 'future' shows the present value of the amounts that each member of the generations born after 2002 will pay, on average (assuming that the tax bill of each person in the future generations will rise at the rate of productivity growth, PGR). In the case of Net Tax Payment 1, each member of the urban male generations born after 2002 will get a bill from the central and local governments for RMB79,633, which is 43.6 per cent larger than the bill paid by the urban males in 2002 (the zero-age males). Since the reported net tax of the future generations is income-adjusted, ${ }^{10}$ the ratio (net tax of future generations/ net tax of zero-age generation) is a proxy for the ratio of the two tax rates paid by the future generations and the zero-age generation: that is, the tax rate of the future generations is about 44 per cent higher than the tax rate paid by the zeroage generation.

In the case of Net Tax Payment 2, the bill amounts to RMB74,379 for urban males, which is 40.54 per cent larger than the bill facing zero-age males in 2002. 


\begin{tabular}{|c|c|c|c|c|}
\hline \multirow{2}{*}{$\begin{array}{l}\text { Table } 8.3 \\
\text { Scenarios }\end{array}$} & \multicolumn{4}{|c|}{$\begin{array}{l}\text { The ratio of per capita net tax payments of future generations } \\
\text { to the zero-age generation in } 2002 \text { under different retirement } \\
\text { age assumptions }^{\text {a }}\end{array}$} \\
\hline & $\begin{array}{l}\text { Base case male: } 60 \\
\text { female: } 50-55\end{array}$ & All: 60 & All: 63 & $\begin{array}{l}\text { Male: } 65 ; \\
\text { female: } 60\end{array}$ \\
\hline Net Tax (1) & 1.4364 & 1.1826 & 1.0031 & 0.9822 \\
\hline Net Tax (2) & 1.4054 & 1.1598 & 0.9858 & 0.9655 \\
\hline
\end{tabular}

Note: a Ratio is a proxy for the ratio of the tax rates paid by the future generations and the zero-age generation.

Source: Reproduced from Jiang, Y., Ruoen, R. and Woo, W.T., 2006. A generational accounts analysis of China's fiscal fituation: que sera sera, the future's not ours to see?, manuscript, University of California.

The impact of retirement age on intergenerational inequity

In China, the present retirement age is 60 for urban males, 55 for urban female cadres and 50 for urban female workers. As the life expectancy in China is 74 for urban males and 78 for urban females, compared with the average life expectancy of 76 for people in industrial countries, the retirement age is much younger in China than in industrial countries.

Table 8.3 reports JRW's results of how intergenerational equity changed with different retirement-age assumptions for urban residents. The scenario labelled 'All: 60 ' means that the retirement age is 60 from 2003 onwards. The scenario labelled 'All: 63' means that the retirement age is 63 from 2003 onwards. The scenario labelled 'male: 65; female: 60' means that the retirement age from 2003 onwards is 65 for males and 60 for females. JRW found that the generational balance was essentially achieved in the 'All: 63' scenario and the 'male: 65; female: 60' scenario.

\section{Concluding remarks}

The state budget is often called on to change spending flows to stabilise price levels, to apply the grease of infrastructure investments to crash through production bottlenecks that are hindering economic growth, and to supply the financial glue to hold the polity together. It is therefore hard to overemphasise the importance of fiscal soundness in economic management.

We have used the standard stock-flow approach and the newer generational accounts approach to examine China's fiscal regime. The strong conclusion from the stock-flow analysis is that frequent bank recapitalisation is the biggest threat 
to China's fiscal solvency, and that the recapitalisation of the state-owned banks that has been happening since 1996 is the last such recapitalisation that China can afford.

Because fiscal solvency is ensured when the State keeps interest rates low through regulation to contain the cost of debt service, China faces a difficult trade-off between easy debt management and the promotion of financial market development via bank recapitalisation and interest rate deregulation.

The strong conclusion of the generational accounting approach is that the present fiscal regime produces severe intergenerational inequity in tax burdens. A member of a future generation will pay a tax rate that is about 40 per cent higher than the tax rate paid by a member of today's generation.

Our analysis arrives at three main policy suggestions to reduce China's vulnerability to possible future fiscal difficulties.

1. Increase the extractive capacity of the State so that the revenue-GDP ratio increases to 25 per cent in the medium term. This extra revenue will be the fiscal cushion that allows the State to accommodate unexpected expenditure demands or revenue shortfalls. As noted earlier, the collection of revenue might first require overcoming the challenge of forging the political consensus for a tax increase.

2. Reform the management of state assets and the regulation of the financial sector to eliminate the phenomenon of repeated recapitalisation of stateowned banks. The privatisation of some units of the state-owned banks, and the emergence of large domestic private banks, will help strengthen the budget constraints perceived by the managers of state-owned banks.

3. Raise the retirement age of the urban population to remove pressures on the pension system. This move would also accommodate the new demands of a population that is experiencing an increase in life expectancy and an improvement in physical health.

\section{Notes}

1 See Bates (2005) for examples of African governments falling after removing food subsidies, and see Cooper (1971) for examples of government changes after currency devaluations. President Suharto of Indonesia was pushed out of office in May 1998, one month after raising fuel prices.

2 Of course, a strong fiscal position cannot overcome all challenges: for example, when a challenger thinks that he can assume political power and hence take control of the fiscal mechanism, it will be very difficult to bribe him to go away.

3 See Auerbach et al. 1994; Kotlikoff 1993; and Jiang et al. 2006 for discussions of the differences between these two approaches. 
4 I might, in short, be applying the generational accounts approach to a concept (sustainability) that was not intended by its founders, Auerbach et al. (1991).

5 Available from http://stats.oecd.org/wbos/ viewhtml.aspx?QueryName=2\&QueryType=View\&Lang=en

6 Except for Luxembourg, which was excluded because of its atypical nature.

7 The asymmetry is from the absence of financial punishment when a loss occurs.

8 As the generational accounting approach assumes that the per capita tax burden of future generations increases at the rate of productivity growth and compares the tax burden of future generations with the tax burden of the generation born this year (labelled generation zero), this comparison of the two amounts paid is also a comparison of the tax rate paid by future generations and the tax rate paid by generation zero.

9 JRW is not the first application of the generational accounting approach to Chinese data. The first was by Ren et al. 2004. The generational accounts approach to analysing fiscal regimes has of course already been applied to many countries, for example, in Auerbach and Chun 2005; Banks et al. 1999; and Hagemann and Christoph 1997.

10 In JRW's computation, the amount of the net tax of the future generations rises in proportion with the rise in income: that is, net tax will automatically go up 10 per cent when incomes rise by 10 per cent. What is meant here? I think a word/s is missing or has been repeated. 